\title{
Determination and risk assessment of heavy metals in air dust fall particles
}

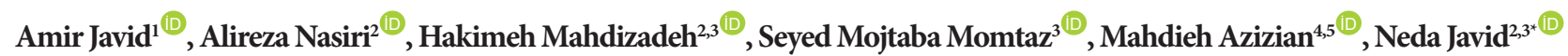 \\ ${ }^{1}$ Department of Civil Engineering, School of Technical and Engineering, Shiraz Payam-e-Noor University, Shiraz, Iran \\ ${ }^{2}$ Environmental Health Engineering Research Center, Kerman University of Medical Sciences, Kerman, Iran \\ ${ }^{3}$ Department of Environmental Health Engineering, Zarand School of Nursing, Kerman University of Medical Sciences, Kerman, Iran \\ ${ }^{4}$ Modeling in Health Research Center, Institute for Futures Studies in Health, Kerman University of Medical Sciences, Kerman, Iran \\ ${ }^{5}$ Department of General Education, Afzalipour School of Medicine, Kerman University of Medical Sciences, Kerman, Iran
}

\begin{abstract}
Background: Urban and industrial development has increased the concentration of heavy metals in various environments, and also, increased their amount in dust fall particles. The aim of this study was to determine and assess the risk of heavy metals in air dust fall particles.

Methods: Sampling of air dust fall particles was performed using the British model Dust Fall Jar devices. Heavy metals concentrations in the samples were determined using an atomic absorption spectrometer device. Then, the risk assessment of heavy metals in air dust fall was calculated by three indicators including enrichment factor $(\mathrm{EF})$, geo-accumulation index $\left(\mathrm{I}_{\text {geo }}\right)$, and integrated pollution index (IPI). Data were analyzed using descriptive statistics and Excel 2016 software.

Results: $\mathrm{Zn}$ was the most abundant heavy metal. The results of $\mathrm{EF}$ index showed that the highest degree of enrichment of dust fall particles with heavy metals is related to $\mathrm{Ag}$ and the lowest one is related to Cr. Also, the changes of Mean of both $\mathrm{I}_{\text {geo }}$ and IP indicators were $\mathrm{as} \mathrm{Ag}>\mathrm{Pb}>\mathrm{Zn}>\mathrm{Cd}>\mathrm{Cu}>\mathrm{Co}>\mathrm{Cr}$. Conclusion: According to the results, it can be concluded that $\mathrm{Cr}$ metal is originated from the earth and other metals are of man-made origin and are mainly due to the emissions of vehicles and industries. Also, on average, the samples had very low pollution in relation to all metals. Although the amount of pollution caused by heavy metals has not exceeded the allowable limits, but considering industrial development programs in the region, continuous measures to control air pollution caused by industries, are absolutely necessary.

Keywords: Metals, Air pollution, Risk assessment

Citation: Javid A, Nasiri A, Mahdizadeh H, Momtaz SM, Azizian M, Javid N. Determination and risk assessment of heavy metals in air dust fall particles. Environmental Health Engineering and Management Journal 2021; 8(4): 319-327. doi: 10.34172/EHEM.2021.36.
\end{abstract}

\section{Introduction}

Dust is a regional and international problem, and also, one of the most important environmental disasters. Natural dust storms, which often occur in arid and semi-arid regions of the world, can carry large amounts of material (1). Dust particles are an important cause of urban environmental pollution, which consists of soil, air particles, building materials, soot from industries and vehicles, heavy metals, etc., and many studies have shown that dust particles have a high ability to carry heavy metals $(2,3)$.

Heavy metals are a major environmental problem worldwide due to their toxicity, non-degradability, and widespread pollution as a result of industrial and urban growth $(4,5)$. Pollution of the environment with heavy metals are due to mining, coal burning, traffic emissions, surface runoff, waste water disposal and agricultural activities, pesticide industries, pigments, petrochemical industries, paper making and refineries etc $(6,7)$.

Heavy metals that are formed in fine and light compounds remain suspended in the ambient air and in case of rain, some of these pollutants are dissolved in the rain and return to the earth's surface and some of the heavy metals in the heavy particles are deposited over time and reach the surface of the earth (dust fall particles). In general, the presence of heavy metals in the air or in the dust present in the air increases the concentration of these elements in the body of residents of contaminated areas through ingestion, respiration and skin absorption $(8,9)$. These dust fall particles in addition to polluting the air, are concentrated in the soil after reaching the ground level, and then, the contaminated soils are considered as secondary environmental hazards in two ways: contamination of grains and vegetables and groundwater contamination by 
the migration of heavy metals from the soil system to the water, especially when the soil is used for agriculture (10).

The harmful effects of heavy metals on the human health have been proven in various ways and exposure to these pollutants causes acute and chronic poisoning and many diseases such as neurological disorders, nutritional deficiencies, hormonal imbalances, obesity, abortion, respiratory and cardiac disorders, liver and kidney damage, allergy and asthma, chronic viral infections, decreasing tolerance threshold, infertility, anemia, weakening of the immune system, gene destruction, premature aging, decreasing memory, osteoporosis, hair loss, insomnia, cancers, and death (11). The effects of heavy metals on plants are inhibition of seed germination and plant growth, abnormalities in plants, destruction of many biochemical and physiological processes including damage to the photosynthetic apparatus and decreasing photosynthetic rate, effect on the activity of some enzymes etc.(12). Many studies have been done in different parts of the world regarding the concentration of these metals in soil and air dust fall particles. Gulson and Taylor in Australia, predicted the concentration of lead in the blood of children by measuring the concentration of lead in dust fall particles. Based on statistical analysis, they found that there was a significant relationship between the concentration of lead in the particles and the concentration of lead in the blood, and they had a direct relationship with each other (13). Rahman et al in Bangladesh, assessed the risk to human health from heavy metal contamination through street dust. This study showed that the concentrations of nickel, lead, cadmium, and arsenic are slightly higher than their concentrations in the soil. They also found that lead, zinc, copper, cobalt, and chromium contamination were associated with industrial activity and heavy traffic (14). In China, Leung et al collected dust fall particles on surfaces of school grounds and roadsides, and measured the concentration of heavy metals in the collected samples. The concentrations of metals in roadside dust for lead and zinc were 22600 and $2370 \mathrm{mg} / \mathrm{kg}$, respectively. In schools, the concentrations of lead, zinc, chromium, and cadmium were 5 to 10,30 to 50,700 to 800,800 to $1000 \mathrm{mg} / \mathrm{kg}$, respectively (15). The results of this study are consistent with the results of studies conducted in Iran and other parts of the world (16-23).

Air pollution from heavy metals is a serious global threat to humans, natural ecosystems, water resources and facilities, and is a major threat to human health and the environment in the future. These pollutions are the result of increasing agricultural operations, urban planning, and industrial projects. Due to the danger of heavy metals for the lives of living organisms, sufficient information about the type and amount of each of them in the urban environment is of great importance (24).

The purpose of this study was to determine and assess the risk of heavy metals in air dust fall particles of cities using $\mathrm{I}_{\text {geo }}$, IPI, and EF indicators, and as a case study, the relatively industrial city of Zarand, in where no similar study has been conducted, was selected.

\section{Material and Methods Study area}

It is an experimental cross-sectional study that was conducted in the first six months of 2020. In this study, Zarand city in Kerman province was selected as a case study due to the establishment of various industries around it and their effective role in air pollution. Industries such as steel, coking, tar refinery, pelletizing, etc. are located around the city. Zarand city is located in the northwest of Kerman province and in $30^{\circ} 33^{\prime}-31^{\circ} 24^{\prime} \mathrm{N}$ and $55^{\circ} 39^{\prime}-56^{\circ}$ $56^{\prime} \mathrm{E}$ and it has a semi-desert climate. The geographical location of this city in relative to the center of the province and the country is shown in Figure 1.

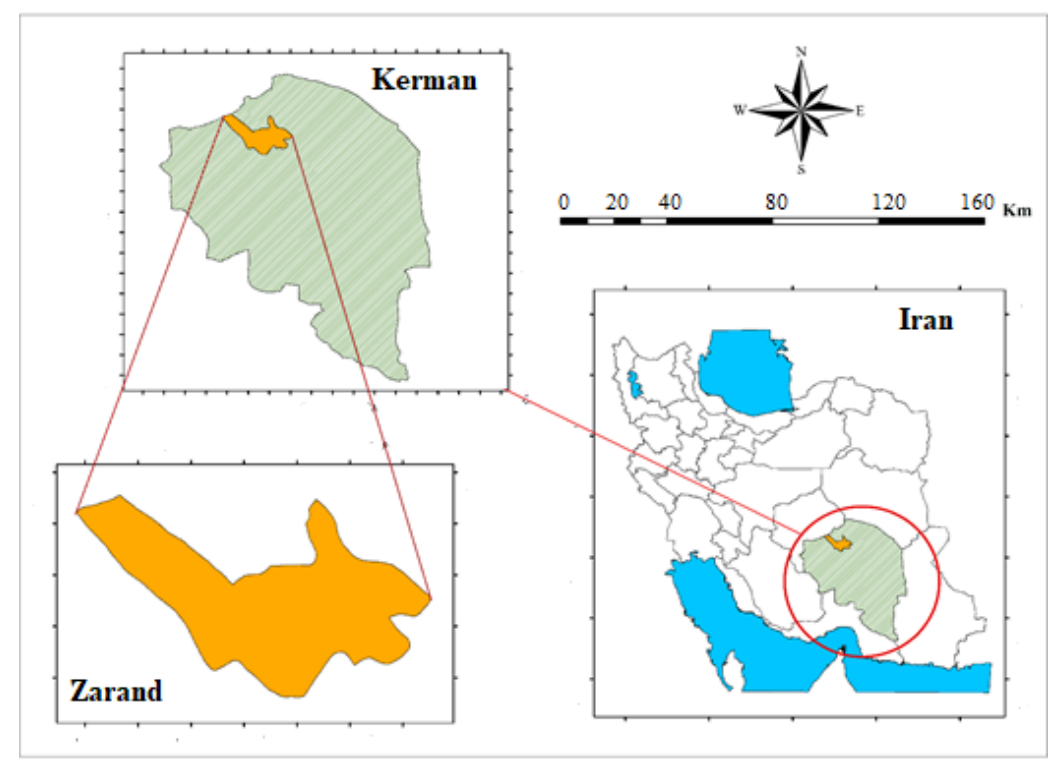

Figure 1. The geographical location of Zarand city. 


\section{Collection and preparation of samples}

Dust fall jar devices were used for sampling. Sampling stations were selected based on the ASTM recommendations and standard sampling methods in order to cover the entire city (25-27). Based on previous contents, sampling stations were located in 10 points of Zarand city and at a height of 3 meters above the ground. The location of the stations is shown in Figure 2 and the name of the sampling points with their geographical coordinates are given in Table 1. Sampling of dust fall particles was performed in the middle of spring and summer of 2020 for one month in all 10 selected stations. In this study, the standard English sampling device (BS 1774) was used (26). Figure 3 shows the standard English sampler (BS) of dust fall particles.

Dust fall particles accumulated in the dust fall jars were washed with distilled water and were entered the device's

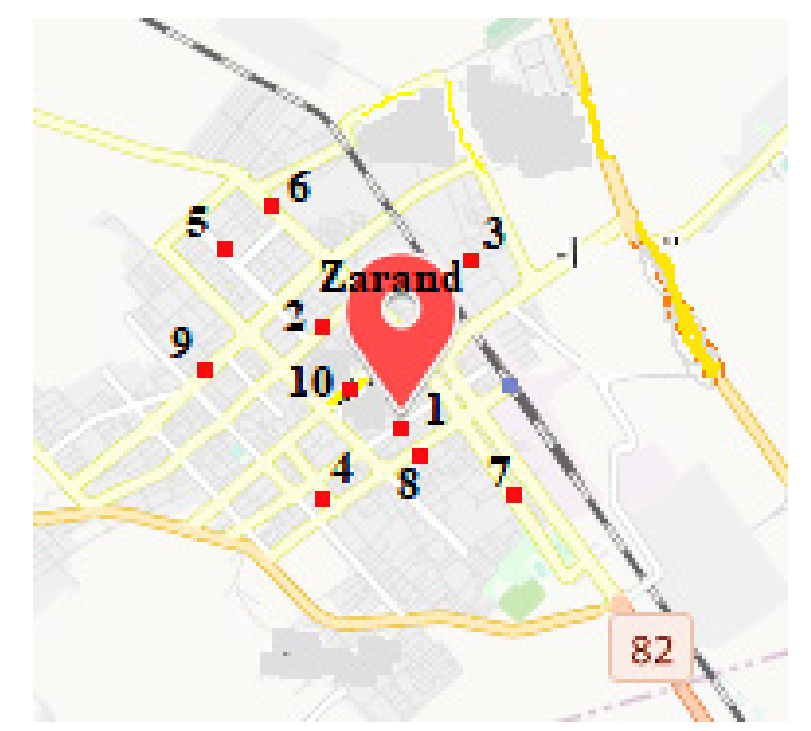

Figure 2. Location of dust fall particle sampling stations.

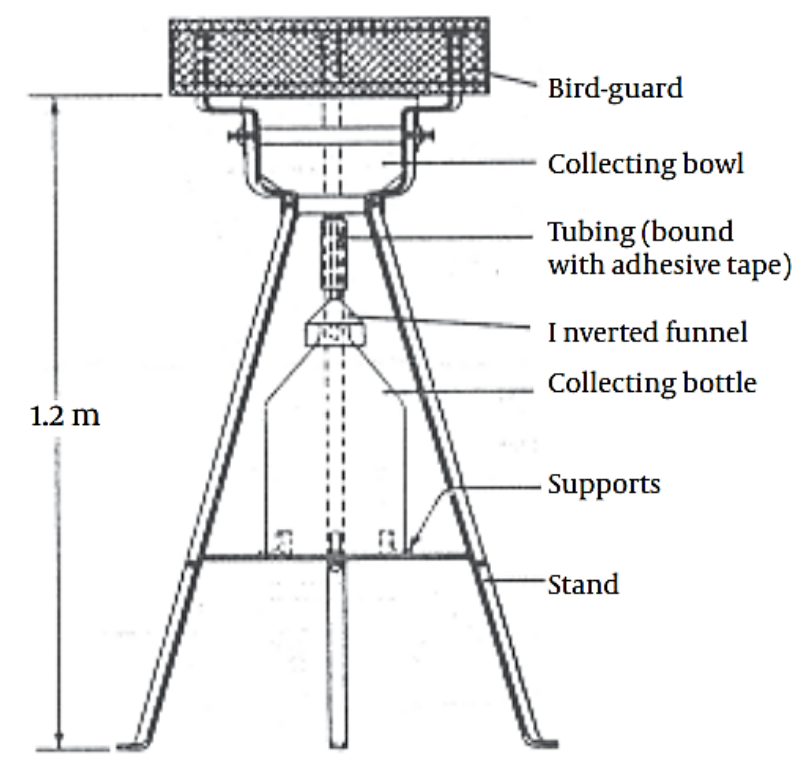

Figure 3. Standard english sampler (BS 1774) of dust fall particles used in the study of Zarand city (26).
Table 1. The name of the sampling points and their geographical coordinates

\begin{tabular}{lcc}
\hline No. & Sampling Sites & Geographical Coordinates \\
\hline 1 & 17 Shahrivar St & $30^{\circ} 81^{\prime} \mathrm{N}, 56^{\circ} 57^{\prime} \mathrm{E}$ \\
\hline 2 & Bahonar St & $30^{\circ} 81^{\prime} \mathrm{N}, 56^{\circ} 56^{\prime} \mathrm{E}$ \\
\hline 3 & $30^{\circ} 81^{\prime} \mathrm{N}, 56^{\circ} 57^{\prime} \mathrm{E}$ \\
\hline 4 & Velayat town & $30^{\circ} 79^{\prime} \mathrm{N}, 56^{\circ} 57^{\prime} \mathrm{E}$ \\
\hline 5 & Gharani St & $30^{\circ} 82^{\prime} \mathrm{N}, 56^{\circ} 56^{\prime} \mathrm{E}$ \\
\hline 6 & Jannat St & $30^{\circ} 83^{\prime} \mathrm{N}, 56^{\circ} 55^{\prime} \mathrm{E}$ \\
\hline 7 & Emam Hossain Blvd & $30^{\circ} 48^{\prime} \mathrm{N}, 56^{\circ} 33^{\prime} \mathrm{E}$ \\
\hline 8 & Takhti St & $30^{\circ} 48^{\prime} \mathrm{N}, 56^{\circ} 34^{\prime} \mathrm{E}$ \\
\hline 9 & Beheshti St & $30^{\circ} 48^{\prime} \mathrm{N}, 56^{\circ} 33^{\prime} \mathrm{E}$ \\
\hline 10 & Jomhoori Blvd & $30^{\circ} 80^{\prime} \mathrm{N}, 56^{\circ} 55^{\prime} \mathrm{E}$ \\
\hline
\end{tabular}

tank. After transferring to the laboratory, the contents of the tank were heated for 2 hours at $105^{\circ} \mathrm{C}$ in order to reduce the volume of the solution and after cooling, it was filtered using Whatman filter No. 42. Then, $0.15 \mathrm{~g}$ of the remaining insoluble contents on Whatman filter were digested with $12 \mathrm{~mL}$ of concentrated nitric acid and concentrated hydrochloric acid (ratio 1 to 3 ) and were heated for 2 hours at $95^{\circ} \mathrm{C}$. Then, they were filtered again with Whatman filter No. 42 and the obtained solutions reached a volume of $25 \mathrm{~mL}(1,2)$. Finally, the solutions were injected into the detector to measure the concentration of the heavy metals $(\mathrm{Zn}, \mathrm{Pb}, \mathrm{Ag}, \mathrm{Cu}, \mathrm{Co}$, $\mathrm{Cr}, \mathrm{Cd}$ ). Atomic absorption spectrometry was used to analyze the samples and to control the quality of the results (1). The experiments were performed twice. Data were analyzed using descriptive statistics and Excel 2016 software.

\section{Evaluation of heavy metals in dustfall}

The amounts of heavy metals measured in the samples were evaluated with the following 3 indicators (28):

\section{Geo-accumulation index}

According to Eq. (1), the geo-accumulation index $\left(\mathrm{I}_{\text {geo }}\right)$ calculates heavy metal contamination according to the ratio of the concentration of each heavy metals in the samples to the background concentration of them in the earth's crust:

$\mathrm{I}_{\text {geo }}=\log _{2}\left(\frac{\mathrm{Cn}}{1.5 \mathrm{Bn}}\right)$

Where $I_{\text {geo }}$ is geo-accumulation index, $C_{n}$ is measured concentration of heavy metal in the sample $(\mathrm{mg} / \mathrm{kg}), B_{n}$ is the geochemical background concentration $(\mathrm{mg} / \mathrm{kg})$, constant 1.5 allows us to analyze the natural fluctuations of the constituents of a substance in the environment and to detect very little human impact.

\section{Integrated pollution index}

The integrated pollution index (IPI) index provides an 
average of the ratio of the concentration of heavy metals in the samples to the background concentration of the same metals in the earth's crust (PI). PI is calculated according to Eq. (2):

$\mathrm{PI}_{\mathrm{i}}=\mathrm{C}_{\mathrm{i}} / \mathrm{B}_{\mathrm{i}}$

Where $C_{i}$ is measured concentration of heavy metal in the sample $(\mathrm{mg} / \mathrm{kg}), B_{i}$ is the geochemical background concentration $(\mathrm{mg} / \mathrm{kg})$, and $i$ is the number of heavy metals measured.

Finally, the quantity of IPI index is calculated as the average of PI values for all measured heavy metals (1).

\section{Enrichment factor}

Enrichment factor (EF) is a common approach to investigate the contribution of human activities to heavy metal contamination and to distinguish human origin from natural origin. This method is based on the calculation of the concentration of metals to the concentration of the same metals in the non-contaminated area (earth's crust). Basically, as the amount of EF increases, the share of non-crust sources also increases. These concentrations are measured based on the concentration of the reference element, which can be aluminum, iron, manganese (16,
17). Aluminum is a conservative element and a major constituent of soil that has been used successfully by several scientists (28).

This factor is calculated using Eq (3):

$\mathrm{EF}=\frac{\left(\frac{\mathrm{CMetal}}{\mathrm{RE}}\right) \text { sample }}{\left(\frac{\mathrm{CMetal}}{\mathrm{RE}}\right) \text { earth's crust }}$

Where $E F$ is enrichment factor, $C_{\text {Metal }}$ is concentration of metal in samples and earth's crust $(\mathrm{mg} / \mathrm{kg})$, and $R E$ is concentration of reference metal (Aluminium) in samples and earth's crust ( $\mathrm{mg} / \mathrm{kg}$ ).

Table 2 shows the classification of pollution levels based on the three indicators and Table 3 shows the average concentration of heavy metals in the earth's crust.

Results

\section{Heavy metal concentration in samples}

Table 4 shows the maximum, minimum, average and other statistical information on the concentration of heavy metals in air dust fall particles.

According to Table 4 and Figures 3 and 4, $\mathrm{Zn}$ was the most abundant heavy metal and had the highest average value $(4 \mathrm{mg} / \mathrm{kg})$. The lowest average value $(0.003 \mathrm{mg} /$ $\mathrm{kg}$ ) belonged to $\mathrm{Cd}$. In general, changes in the average concentration of heavy metals measured were as $\mathrm{Zn}>\mathrm{Pb}$

Table 2. The classification of pollution levels based on $\mathrm{I}_{\text {geo }}$, IPI, and EF indicators $(1,28)$

\begin{tabular}{|c|c|c|c|c|c|}
\hline \multicolumn{2}{|c|}{ Geo-Accumulation Index (Igeo) } & \multicolumn{2}{|c|}{ Integrated Pollution Index (IPI) } & \multicolumn{2}{|c|}{ Enrichment Factor (EF) } \\
\hline Value & Dust Quality & Value & Dust Quality & Value & Dust Quality \\
\hline $\operatorname{lgeo} \leq 0$ & Uncontaminated & $\mid \mathrm{PI}<1$ & Low contamination & $\mathrm{EF}<2$ & Deficiency to minimal enrichment \\
\hline $0<$ Igeo $<1$ & Uncontaminated to moderately contaminated & $1<\mathrm{IPI}<2$ & Moderately contaminated & $2<E F<5$ & Moderate enrichment \\
\hline $1<\operatorname{lgeo}<2$ & Moderately contaminated & $2<\mid \mathrm{PI}<5$ & High contamination & $5<\mathrm{EF}<20$ & Significant enrichment \\
\hline $2<$ Igeo $<3$ & Moderately to heavily contaminated & $\mid \mathrm{PI}>5$ & Heavily contaminated & $20<E F<40$ & Very high enrichment \\
\hline $3<$ Igeo $<4$ & Heavily contaminated & & & $E F>40$ & Extremely high enrichment \\
\hline $4<\operatorname{lgeo}<5$ & Heavily to extremely contaminated & & & & \\
\hline $\operatorname{lgeo} \geq 5$ & Extremely contaminated & & & & \\
\hline
\end{tabular}

Table 3. The average concentration of heavy metals in the earth's crust $(\mathrm{mg} / \mathrm{kg})(17,29)$

\begin{tabular}{|c|c|c|c|c|c|c|c|}
\hline Heavy Metals & $\mathrm{Ag}$ & $\mathrm{Cu}$ & Cd & Co & $\mathrm{Cr}$ & $\mathrm{Pb}$ & $\mathrm{Zn}$ \\
\hline Average concentration of heavy metals in the earth's crust & 0.07 & 55 & 0.2 & 25 & 100 & 12.5 & 70 \\
\hline
\end{tabular}

Table 4. Statistical results related to the concentration of heavy metals in dust fall particles

\begin{tabular}{|c|c|c|c|c|c|c|c|}
\hline \multirow{2}{*}{ Heavy metals (mg/kg) } & \multicolumn{7}{|c|}{ Statistics } \\
\hline & Mean & Minimum & Maximum & Range & SD & Skewness & CV (\%) \\
\hline $\mathrm{Ag}$ & 0.09 & 0.048 & 0.172 & 0.124 & 0.047 & 0.001 & 52 \\
\hline $\mathrm{Cu}$ & 0.477 & 0.136 & 0.941 & 0.805 & 0.255 & 0.0004 & 53 \\
\hline $\mathrm{Cd}$ & 0.003 & 0.001 & 0.007 & 0.006 & 0.002 & 0.001 & 66 \\
\hline Co & 0.145 & 0.011 & 0.464 & 0.453 & 0.128 & 0.001 & 88 \\
\hline $\mathrm{Cr}$ & 0.286 & 0.129 & 0.485 & 0.356 & 0.132 & 0.0002 & 46 \\
\hline $\mathrm{Pb}$ & 1.01 & 0.01 & 2.5 & 2.49 & 0.97 & 0.0001 & 96 \\
\hline $\mathrm{Zn}$ & 4 & 1 & 7.7 & 6.7 & 0.002 & 0.0002 & 0.05 \\
\hline
\end{tabular}

SD: Standard deviation; CV: Coefficient of variation. 


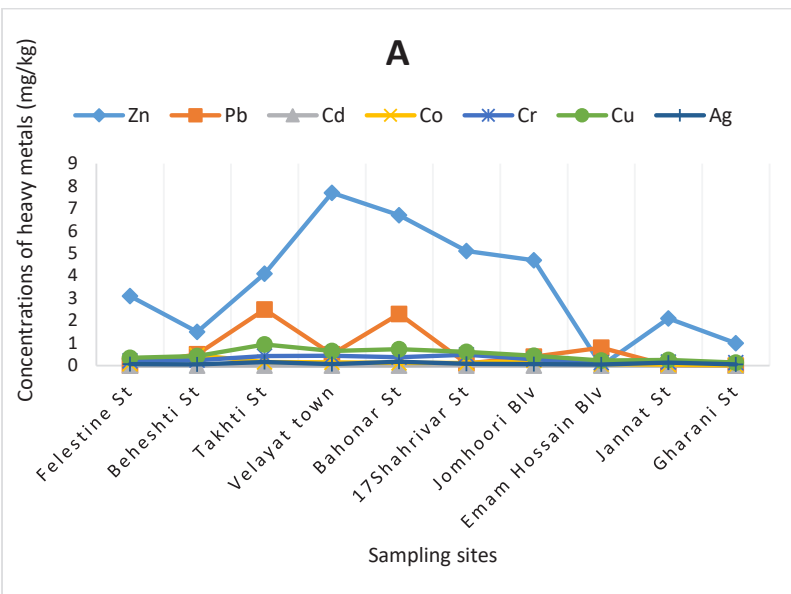

B

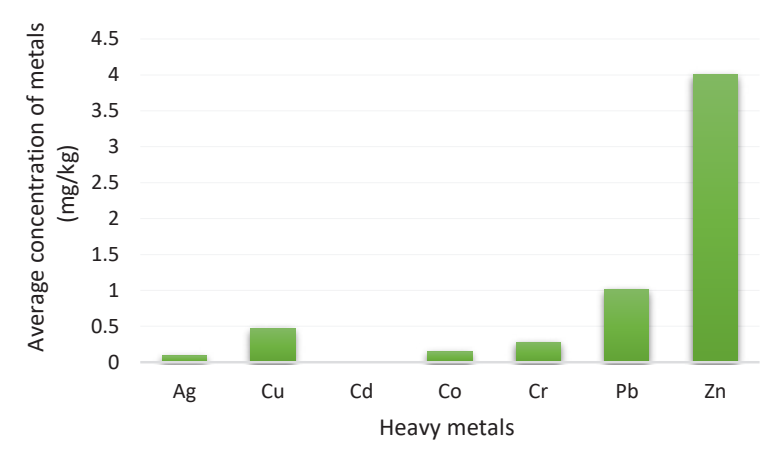

Figure 4. The changes in the concentration of heavy metals in dust fall particles at different sampling sites (A) and average concentration of heavy metals in dust fall particles (B).

\section{$>\mathrm{Cu}>\mathrm{Cr}>\mathrm{Co}>\mathrm{Ag}>\mathrm{Cd}$.}

The coefficient of variation $(\mathrm{CV})$ indicates the degree of variability of the concentrations of heavy metals in dust fall particles. When $\mathrm{CV} \leq 20 \%, 21 \% \leq \mathrm{CV}<50 \%$, and $50 \% \leq$ $\mathrm{CV}<100 \%$, it indicates low variability, medium variability, and high variability, respectively. Coefficients of variation above $100 \%$ indicate extremely high variability (17). In general, the $\mathrm{CV}$ changes of heavy metals concentrations in dust fall particles in the study area were as $\mathrm{Pb}>\mathrm{Co}>\mathrm{Cd}>$ $\mathrm{Cu}>\mathrm{Ag}>\mathrm{Cr}>\mathrm{Zn}$.

Also, changes in the standard deviation (SD) of heavy metals concentrations in the dust fall particles in the study area were as $\mathrm{Pb}>\mathrm{Cu}>\mathrm{Cr}>\mathrm{Co}>\mathrm{Ag}>\mathrm{Cd}$ and $\mathrm{Zn}$. The skewness amount of all heavy metals was positive.

Changes in the concentration of heavy metals in dust fall particles at different sampling sites and the average concentration of heavy metals are shown in Figure 4(A) and (B), respectively.

\section{Evaluation of heavy metals}

According to Table 5, it was found that the average EF changes are as $\mathrm{Ag}>\mathrm{Pb}>\mathrm{Zn}>\mathrm{Cd}>\mathrm{Cu}>\mathrm{Co}>\mathrm{Cr}$. The results of the EF and its mean are shown in Figure 5(A) and (B), respectively.

As shown in this figure, the highest degree of enrichment of dust fall particles with metals based on the EF index is related to Ag and the lowest one is related to Cr. According to the equations for the $\mathrm{EF}$, if the value of this factor is less than 10, it indicates that the metals in the dust fall particles is from the sources of the earth's crust, and if it is above 10, it indicates anthropogenic sources (16). Among the measured heavy metals, all of them had EF> 10, only Cr metal had $\mathrm{EF}<10$.

The average changes of both $\mathrm{I}_{\text {geo }}$ and IPI indicators were as $\mathrm{Ag}>\mathrm{Pb}>\mathrm{Zn}>\mathrm{Cd}>\mathrm{Cu}>\mathrm{Co}>\mathrm{Cr}$ and these two indicators also showed that the highest and lowest enrichment of dust fall particles with heavy metals were related to $\mathrm{Ag}$ and $\mathrm{Cr}$, respectively. Figures $6 \mathrm{~A}-\mathrm{B}$ and $7 \mathrm{~A}-\mathrm{B}$ show changes in $\mathrm{I}_{\text {geo }}$, $\mathrm{I}_{\text {geo }}$ average, IP and IP average (IPI) for heavy metals measured at sampling stations, respectively.

The results showed that the values of $\mathrm{I}_{\text {geo }}$ index for all heavy metals measured except $\mathrm{Cr}\left(\mathrm{I}_{\text {geo }}=0\right)$, in all samples were as $0<\mathrm{I}_{\text {geo }}<1$ and the highest value of this index was related to $\mathrm{Ag}$ and $\mathrm{Pb}$. Also, the results showed that the IPI index values for all heavy metals measured except Ag (1 $<$ IPI $<2$ ), in all samples was as IPI $<1$. In other words, the average of $\mathrm{I}_{\text {geo }}$ and IP indicators showed a completely similar trend for all heavy metals studied in this study (17).

Discussion

The mean of $\mathrm{Zn}$ and $\mathrm{Cd}$ were the maximum and minimum

Table 5. The $\mathrm{I}_{\mathrm{geo}^{\prime}} \mathrm{IPI}$, and EF amounts calculated in the dust fall particle samples

\begin{tabular}{|c|c|c|c|c|c|c|c|c|}
\hline Index & Amounts & $\mathrm{Ag}$ & $\mathrm{Cu}$ & $\mathrm{Cd}$ & Co & $\mathrm{Cr}$ & $\mathrm{Pb}$ & $\mathrm{Zn}$ \\
\hline & Mean & 0.25 & 0.001 & 0.002 & 0.0007 & 0 & 0.01 & 0.008 \\
\hline \multirow[t]{3}{*}{ Igeo } & Maximum & 0.49 & 0.003 & 0.007 & 0.003 & 0 & 0.04 & 0.02 \\
\hline & Minimum & 0.1 & 0 & 0.001 & 0 & 0 & 0 & 0.002 \\
\hline & Mean & 1.28 & 0.007 & 0.01 & 0.004 & 0.002 & 0.05 & 0.04 \\
\hline \multirow[t]{3}{*}{ IP } & Maximum & 2.45 & 0.01 & 0.03 & 0.01 & 0.004 & 0.2 & 0.11 \\
\hline & Minimum & 0.68 & 0.002 & 0.005 & 0 & 0.001 & 0 & 0.01 \\
\hline & Mean & 2986.4 & 16.98 & 23.16 & 10.4 & 6.1 & 194.2 & 97.3 \\
\hline \multirow[t]{2}{*}{$\mathrm{EF}$} & Maximum & 9584 & 30.7 & 62.1 & 48.3 & 16 & 1194 & 177.4 \\
\hline & Minimum & 233 & 11.1 & 9.3 & 1.7 & 3.8 & 2.05 & 55.7 \\
\hline
\end{tabular}




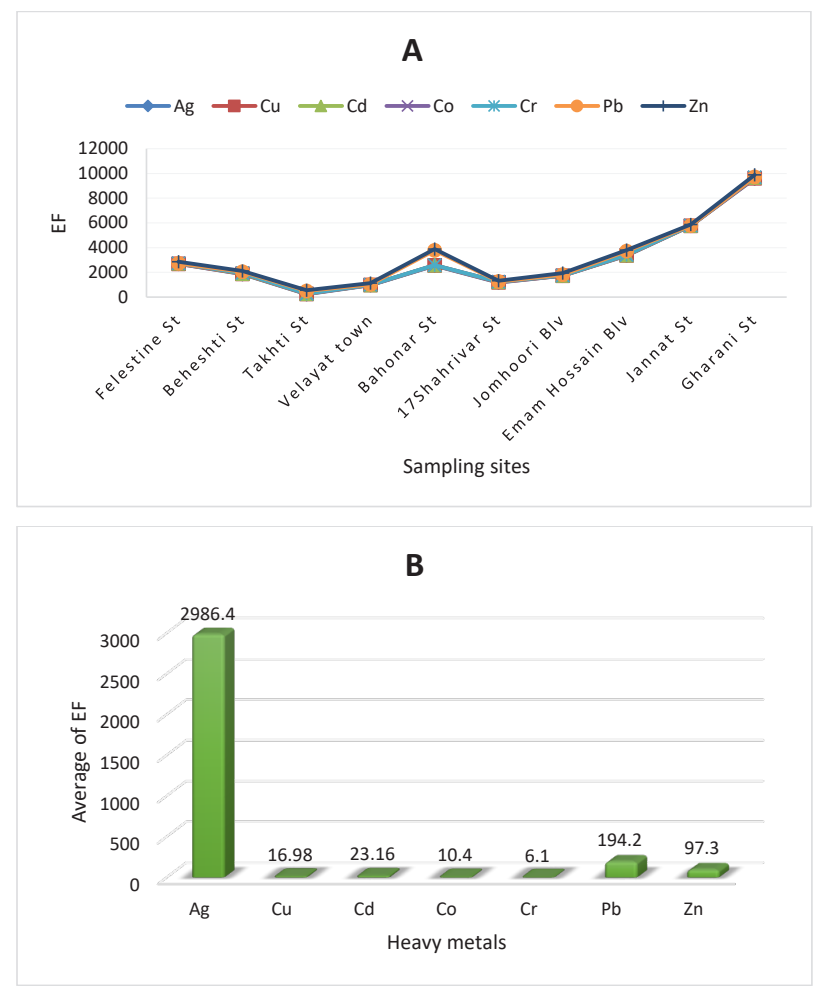

Figure 5. The changes in the amounts of EF index in the dust fall particles (A) and average values of EF index in the dust fall particles (B).

amount, respectively. These results are consistent with the results of the study of Sistani et al (17). The consistency can be due to the similarity of the two regions in terms of proximity to industry. According to the coefficient of variation of the measured metals, it was found that the concentration variability of all metals except $\mathrm{Zn}$ in dust fall particles is high. The high coefficient of variation for these heavy metals indicates that the concentration of these metals varies significantly at different sampling locations, and also, indicates the heterogeneous distribution of these elements in the dust fall particles of the study area. Higher standard deviations of metals in this area indicate a wider range of changes in metal concentrations in the region's dust fall particles. Positive values of metals skewness indicate that these metals have positive skewness towards lower concentrations (17).

All studied metals in the region except Cr, had EF> 10 . The results of this study are consistent with the results of a study by Goodarzi et al that reported the source of $\mathrm{Cr}$ in dust particles is from the earth's crust and the source of other metals is anthropogenic (16). Heidari et al in a study showed that $\mathrm{Cu}$ and $\mathrm{Cr}$ have earth's crust resources and $\mathrm{Zn}$ has industrial sources and vehicles, except for $\mathrm{Cu}$, in other cases, the results are consistent with the results of this study (30). Another study by Mohd Tahir et al showed that the metals $\mathrm{Cd}, \mathrm{An}$, and $\mathrm{Pb}$ were originated from man-made sources and that $\mathrm{Al}$ was originated from the earth's crust (31). In the Zarasvandi et al study, after examining the EF, it was found that the origin of $\mathrm{Cr}$ was man-made activities and the origin of other metals was from the earth's crust (32). The discrepancies between the results of the recent study and the results of this study is the difference in industries located in the two regions, and also, probably the difference in quality in the soil of the two regions under study.

According to the $\mathrm{I}_{\text {geo }}$ index, $30 \%$ of the samples were moderately contaminated with $\mathrm{Ag}$ and $70 \%$ were low contaminated. In the case of $\mathrm{Pb}, 30 \%$ of the samples were not contaminated and $70 \%$ of the samples had very low contamination. In the case of $\mathrm{Zn}, \mathrm{Cd}$, and $\mathrm{Cu}$, all samples had very low contamination. Co was not detected in $50 \%$ of the samples and $50 \%$ of the samples had very low contamination with this metal. No Cr contamination was found in the samples. In the study of Rajabi et al, $\mathrm{I}_{\text {geo }}$ index, contrary to the results of this study, showed a high level of pollution of dust fall particles with $\mathrm{Cu}$, and the high level contamination of dust fall particles with $\mathrm{Ag}$ is a similarity between the results of these two studies. In the case of IPI index, on average, the samples had very low contamination in relation to all heavy metals studied except Ag. The lowest IPI value was related to $\mathrm{Cr}$. In the case of $\mathrm{Ag}$, on average, the samples were moderately contaminated (1).

Comparison of the average concentration of heavy metals studied in this study with other studies showed that the average concentration of Ag in Zarand city is higher than that in cities such as Sanandaj, Andimeshk, and Khorramabad in Iran $(1,33)$. The average concentrations of $\mathrm{Cd}, \mathrm{Co}$, and $\mathrm{Pb}$ in this study were much lower than that reported in other studies in Iran and China (24,30,34). The average $\mathrm{Cr}$ concentration was much lower than that reported in studies in India and China and higher than

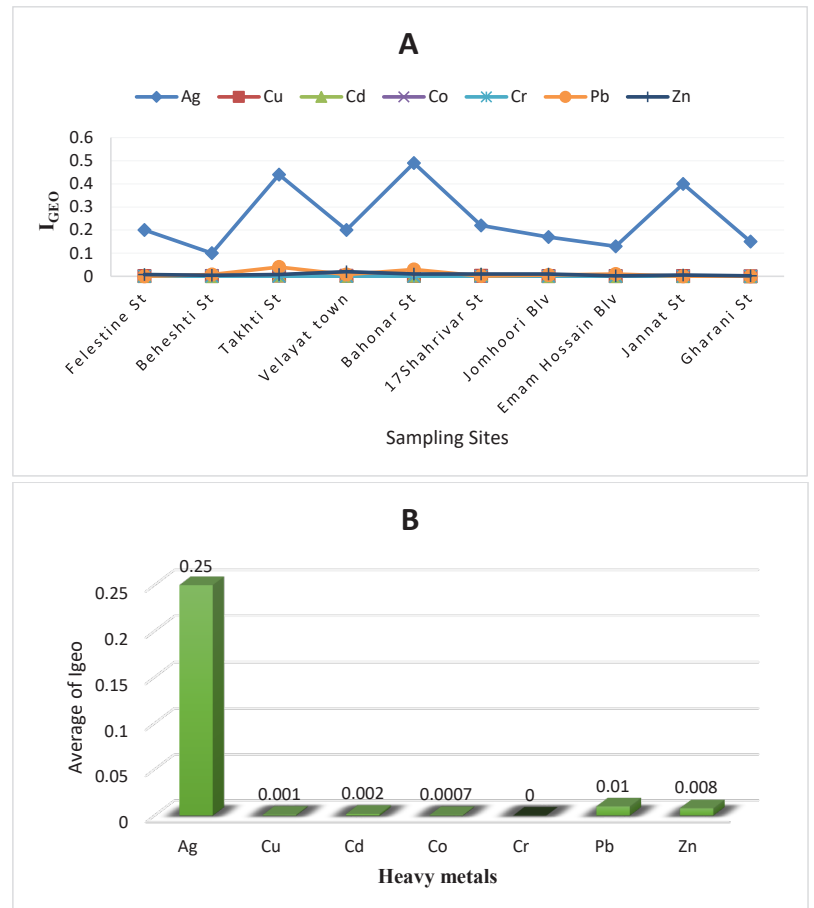

Figure 6. The chart of changes in the amounts of $\mathrm{I}_{\text {geo }}$ index in the dust fall particles (A) and average values of $I_{\text {geo }}$ index in the dust fall particles (B). 


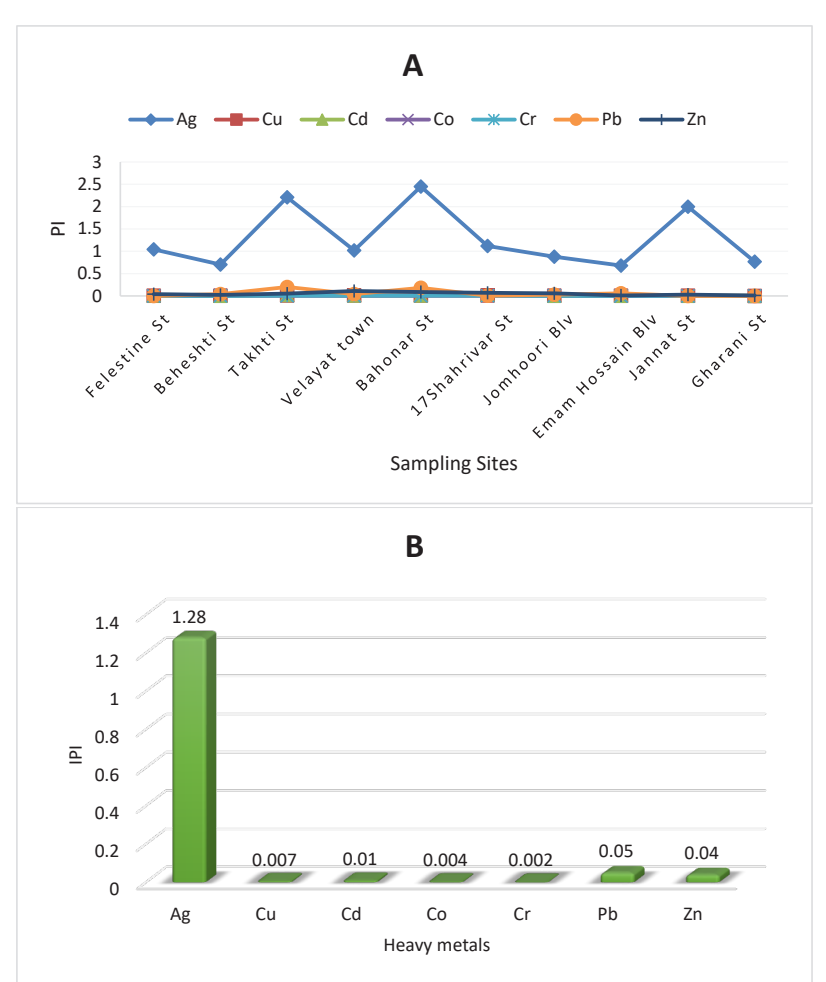

Figure 7. The chart of changes in the amounts of $\mathrm{PI}$ index in the dust fall particles (A) and average values of $\mathrm{PI}$ (IPI) index in the dust fall particles (B).

that reported in Andimeshk, Khorramabad, and Sanandaj in Iran (1). The average zinc concentration was higher than that reported in the studies conducted in three cities in Iran and much lower than that reported in the study conducted in 18 provinces of China $(1,34)$. The discrepancies between the results of this study and those of other studies may be due to differences in industries located in those areas, differences in soil quality of the study areas, and so on.

Comparison of the study results with the results of other studies

Table 6 shows the comparison of the average concentrations of heavy metals measured in this study with the results of other studies. As shown in this table, the average concentration of $\mathrm{Ag}$ in Zarand city is higher than that in other studies.

\section{Conclusion}

The results of EF factor showed that $\mathrm{Cr}$ is originated from earth and other metals such as $\mathrm{Zn}, \mathrm{Pb}, \mathrm{Co}, \mathrm{Cd}, \mathrm{Cu}$, and $\mathrm{Ag}$ have man-made origin and are mainly due to vehicle and industrial emissions. Evaluation of heavy metal content in dust fall particles using $\mathrm{I}_{\text {geo }}$ and IPI indicators confirmed that, on average, samples in relation to all heavy metals have very low pollution, and industrial sources play the most important role in the concentration of heavy metals in air dust fall particles. Therefore, despite the fact that the amount of pollution caused by heavy metals in the dust fall particles has not exceeded the permissible limits, but due to the origin of most of them and industrial development programs in the region, continuous and strict activities to control air pollution from all industries in the city and around it, are absolutely necessary.

\section{Acknowledgments}

This work was conducted in the Environmental Health Engineering Research Center of Kerman University of Medical Sciences and was supported by the ViceChancellor for Research and Technology of Kerman University of Medical Sciences. The authors would like to thank the financial support of the Deputy of the Research Center at Kerman University of Medical Sciences.

\section{Ethical issues}

This study was approved by the Ethics and Research Committee of Kerman University of Medical Sciences (No: 98001066, Ethical code: IR.KMU.REC.1398.651). The authors certify that all data collected during the study are as stated in the manuscript, and no data from the study has been or will be published elsewhere separately.

Table 6. Comparison of mean concentrations of heavy metals $(\mathrm{mg} / \mathrm{kg})$ with the results of other studies

\begin{tabular}{|c|c|c|c|c|c|c|c|c|c|}
\hline City/Country & Soil bed (Dust Fall/Surface Soil/Street Soil) & Ag & $\mathrm{Cu}$ & Cd & Co & $\mathrm{Cr}$ & $\mathrm{Pb}$ & $\mathrm{Zn}$ & References \\
\hline Sanandaj/Iran & Dust fall & 0.0008 & 0.41 & - & - & 0.016 & - & 0.21 & (1) \\
\hline Khorramabad/Iran & Dust fall & 0.0003 & 0.17 & - & - & 0.011 & - & 0.16 & (1) \\
\hline Andimeshk/Iran & Dust fall & 0.0002 & 0.18 & - & & 0.01 & - & 0.18 & (1) \\
\hline Kirk/Jordan & Dust fall & - & 11.3 & - & - & - & - & - & (13) \\
\hline Tehran/Iran & Dust fall & - & 275 & - & - & - & - & - & (23) \\
\hline Shiraz/Iran & Dust fall & - & 136 & - & - & - & - & - & (33) \\
\hline Yazd/Iran & Surface soil & - & - & 29.80 & - & - & 113.11 & - & (27) \\
\hline China & Surface soil & - & 28.60 & 0.24 & - & 63.86 & 28.86 & 77.94 & (34) \\
\hline Alcala/Spain & Surface soil & - & 10.78 & - & - & - & - & - & (35) \\
\hline Delhi city/India & Road dust & - & 168.7 & - & 23.3 & 170.8 & 128.7 & - & (36) \\
\hline Zahedan/Iran & Dust fall & - & 26.49 & - & - & - & - & - & (2) \\
\hline Zarand/Iran & Dust fall & 0.09 & 0.477 & 0.003 & 0.145 & 0.286 & 1.01 & 4 & (This study) \\
\hline
\end{tabular}




\section{Competing interests}

The authors declare that they have no conflict of interests.

\section{Authors' contributions}

All authors were equally involved in the data collection, analysis, and interpretation. All authors critically reviewed, refined, and approved the manuscript.

\section{References}

1. Rajabi M, Souri B. Evaluation of heavy metals among dustfall particles of Sanandaj, Khorramabad and Andimeshk cities in western Iran2012-2013. Iranian Journal of Health and Environment 2015; 8(1): 11-22. [In Persian]

2. Moradi Baseri M, Kamani H, Ashrafi S, Bazrafshan E, Kord Mostafapour F. Non-carcinogenic risk assessment of $\mathrm{Hg}$ and $\mathrm{Cu}$ in streets dusts of Zahedan city. Iranian Journal of Health and Environment 2018; 11(3): 391-402. [In Persian]

3. Khuzestani RB, Souri B. Evaluation of heavy metal contamination hazards in nuisance dust particles, in Kurdistan Province, western Iran. J Environ Sci (China) 2013; 25(7): 1346-54. doi: 10.1016/s1001-0742(12)60147-8.

4. Ogundele LT, Owoade OK, Hopke PK, Olise FS. Heavy metals in industrially emitted particulate matter in Ile-Ife, Nigeria. Environ Research 2017; 156: 320-5. doi: 10.1016/j. envres.2017.03.051.

5. Malakootian M, Mohammadi A, Nasiri A, Asadi A.M.S, Conti G.O, Faraji M, Spatial distribution and correlations among elements in smaller than $75 \mu \mathrm{m}$ street dust: ecological and probabilistic health risk assessment. Environ Geochem Health 2021;43(1) 567-583. doi: 10.1007/s10653020-00694-0.

6. Liu J, Liu YJ, Liu Y, Liu Z, Zhang AN. Quantitative contributions of the major sources of heavy metals in soils to ecosystem and human health risks: A case study of Yulin, China. Ecotoxicol Environ Saf 2018; 164: 261-269. doi: 10.1016/j.ecoenv.2018.08.030.

7. Malakootian M, Mohammadi A, Nasiri A, Conti G.O, Faraji M, Correlation between heavy metal concentration and oxidative potential of street dust. Air Qual Atmos Health 2021 (Article in Press). doi: 10.1007/s11869-02101130-7

8. Murgueytio AM, Evans RG, Sterling DA, Clardy SA, Shadel BN, Clements BW. Relationship between lead mining and blood lead levels in children. Arch Environ Health 1998; 53(6):414-23. doi: 10.1080/00039899809605730.

9. Hawley JK. Assessment of health risk from exposure to contaminated soil. Risk Anal 1985; 5(4): 289-302. doi: 10.1111/j.1539-6924.1985.tb00185.x.

10. Khadem Moghadam Igdelou N, Golchin A. Risk Assessment of Contamination of the Country's Soil and Water Resources with Arsenic. Iranian J Soil Water Research 2019; 50(7): 1595-617. doi: 10.22059/IJSWR.2019.274404.668103. [In Persian]

11. Farahmandkia Z, Mehrasbi M, Sekhavatjou M, Hasan Ama, Ramezanzadeh Z. Study of heavy metals in the atmospheric deposition in Zanjan, Iran. Iranian Journal of Health and Environment 2010; 4(2): 240-249. [In Persian]

12. Karimi M, Norooozion O, Khalafi J. Investigation of heavy metal concentration status of soils around cement plant and its effects. Second National Conference on Science and Technology of Agricultural Sciences, Natural Resources and Environment of Iran, April 6, 2016, Tehran; 2019. p.1-

\section{8. [In Persian]}

13. Gulson B, Taylor A. A simple lead dust fall method predicts children's blood lead level: New evidence from Australia. Environ Res 2017; 159: 76-81. doi: 10.1016/j. envres.2017.07.047.

14. Rahman MS, Khan M, Jolly Y, Kabir J, Akter S, Salam A. Assessing risk to human health for heavy metal contamination through street dust in the Southeast Asian Megacity: Dhaka, Bangladesh. Sci Total Environ 2019; 660: 1610-22. doi: 10.1016/j.scitotenv.2018.12.425.

15. Leung AO, Duzgoren-Aydin NS, Cheung KC, Wong MH. Heavy metals concentrations of surface dust from e-waste recycling and its human health implications in southeast China. Environ Sci Technol 2008; 42(7): 2674-80. doi: 10.1021/es071873x.

16. Goodarzi G, Asgharipour Dashtbozorg N, Naimabadi A, Ghorbanpoor R, Hedari M, Hashemzadeh B, et al. Analysis of chemical properties of precipitating particles in Ahvaz, Iran. Journal of North Khorasan University of Medical Sciences 2018; 9(4): 56-65. doi: 10.29252/nkjmd-09049. [In Persian]

17. Sistani N, Moeinaddini M, Khorasani N, Hamidian A, AliTaleshi M, Azimi Yancheshmeh R. Heavy metal pollution in soils nearby Kerman steel industry: Metal richness and degree of contamination assessment. Iranian Journal of Health and Environment 2017; 10(1): 75-86. [In Persian]

18. Tang Z, Chai M, Cheng J, Jin J, Yang Y, Nie Z, Huang Q, Li Y. Contamination and health risks of heavy metals in street dust from a coal-mining city in eastern China. Ecotoxicol Environ Saf 2017; 138: 83-91. doi: 10.1016/j. ecoenv.2016.11.003.

19. Khatami M, Iravani S. Green and eco-friendly synthesis of nanophotocatalysts: An overview. Comments on Inorganic Chemistry 2021; 41(3): 133-87. doi: 10.1080/02603594.2021.1895127.

20. Khatami M, Iravani S. MXenes and MXene-based Materials for the Removal of Water Pollutants: Challenges and Opportunities. Comments on Inorganic Chemistry 2021; 41(4): 213-248. doi: 10.1080/02603594.2021.1922396.

21. Nazaripour E, Mousazadeh F, Moghadam MD, Najafi K, Borhani F, Sarani M, et al. Biosynthesis of lead oxide and cerium oxide nanoparticles and their cytotoxic activities against colon cancer cell line. Inorganic Chemistry Communications 2021; 131: 108800. doi: 10.1016/j. inoche.2021.108800.

22. Rabiee N, Khatami M, Jamalipour Soufi G, Fatahi Y, Iravani S, Varma RS. Diatoms with invaluable applications in nanotechnology, biotechnology, and biomedicine: Recent advances. ACS Biomater Sci Eng 2021; 7(7): 3053-3068. doi: 10.1021/acsbiomaterials.1c00475.

23. Yadegarnia Naeini F, Azimzadeh H, Mosleh Arani A, Sotoudeh A, Kiani B. Ecological risk assessment of heavy metals from cement factory dust. Environ Health Eng Manag 2019; 6(2): 129-137. doi: 10.15171/ehem.2019.15.

24. Abyareh M, Nejadkoorki F, Ekhtesasi MR, Akhavan Ghalibaf M. Quantitative and qualitative study of industrial dust fall in Yazd (case study of steel industry in Yazd). Iranian Journal of Research in Environmental Health 2019; 5(2): 123-32. [In Persian]

25. S. T. M, (1982), Standard Method For Collection And Analysis For Dustfall (Settlead Particulates). Astm D173982 and Standard Specification For Reagent Water" Astm D-1193-91, 11.03. https://www.document-center.com/ 
standards/show/ASTM-D1739/history/1982\%20EDITION

26. Malakoutian $M$, Ghiasodin $M$, Akbari $H$, JaafarzadehHaghighi Fard NA. Urban dust fall concentration and its properties in Kerman city, Iran. Health Scope 2013; 1(4): 195-201. doi: 10.5812/jhs.8507.

27. Naddafi K, Nabizadeh R, Soltanianzadeh Z, Ehrampoosh MH. Evaluation of dustfall in the air of Yazd. J Environ Health Sci Eng 2006; 3(3): 161-8.

28. Barbieri M. The importance of enrichment factor (EF) and geoaccumulation index (Igeo) to evaluate the soil contamination. J Geol Geophys 2016; 5(1): 1-4. doi: 10.4172/2381-8719.1000237.

29. Taylor S. Abundance of chemical elements in the continental crust: A new table. Geochimica et Cosmochimica Acta 1964; 28(8): 1273-85. doi: 10.1016/0016-7037(64)90129-2.

30. Heidari-Farsani, M., Shirmardi, M., Goudarzi, G., AlaviBakhtiarivand, N., Ahmadi-Ankali, K., Zallaghi, E., Naeimabadi, A., Hashemzadeh, B. The evaluation of heavy metals concentration related to PM10 in ambient air of Ahvaz city, Iran. Journal of Advances in Environmental Health Research 2013; 1(2): 120-128. doi: 10.22102/ jaehr.2013.40133.

31. Mohd Tahir N, Poh SC, Suratman S, Ariffin MM, Shazali NA, Yunus K. Determination of trace metals in airborne particulate matter of Kuala Terengganu, Malaysia. Bull
Environ Contam Toxicol 2009; 83(2): 199-203. doi: 10.1007/ s00128-009-9751-3.

32. Zarasvandi A, Carranza E, Moore F, Rastmanesh F. Spatiotemporal occurrences and mineralogical-geochemical characteristics of airborne dusts in Khuzestan Province (southwestern Iran). J Geochem Explor 2011; 111(3): 13851. doi: 10.1016/j.gexplo.2011.04.004.

33. Keshavarzi B, Tazarvi Z, Rajabzadeh MA, Najmeddin A. Chemical speciation, human health risk assessment and pollution level of selected heavy metals in urban street dust of Shiraz, Iran. Atmos Environ 2015; 119: 1-10. doi: 10.1016/j.atmosenv.2015.08.001.

34. Liu X, Shi H, Bai Z, Zhou W, Liu K, Wang M, et al. Heavy metal concentrations of soils near the large opencast coal mine pits in China. Chemosphere 2020; 244: 125360. doi: 10.1016/j.chemosphere.2019.125360.

35. Acosta JA, Cano AF, Arocena J, Debela F, Martínez-Martínez S. Distribution of metals in soil particle size fractions and its implication to risk assessment of playgrounds in Murcia City (Spain). Geoderma 2009; 149(1-2): 101-9. doi: 10.1016/j.geoderma.2008.11.034.

36. Rajaram B, Suryawanshi P, Bhanarkar A, Rao C. Heavy metals contamination in road dust in Delhi city, India. Environ Earth Sci 2014; 72(10): 3929-38. doi: 10.1007/ s12665-014-3281-y. 